\title{
COMUNICAÇÃO DE MERCADO EM UM AMBIENTE PÓS-MODERNO: A IMATERIALIDADE EM CENA
}

\author{
Market communication in a postmodern environment: The immateriality on the scene
}

\section{Comunicación de mercado en un escenario post-moderno: La inmaterialidad en foco}

\author{
Renata Barreto Malta ${ }^{1}$ \\ Daniel dos Santos Galindo ${ }^{2}$
}

\begin{abstract}
Resumo
O presente artigo é constituído por duas etapas complementares, a teórica e a empírica, essenciais para que o seguinte objetivo proposto seja devidamente cumprido: confirmar uma mudança da práxis publicitária na qual elementos materiais e funcionais passam a ser minimizados e elementos imateriais e intangíveis evidenciados. O aprofundamento teóricoconceitual alicerçado nos Estudos Culturais e em autores que discorrem sobre a pós-modernidade e suas relações de consumo é ponto de partida desta pesquisa.
\end{abstract}

Palavras-chave: publicidade, pós-modernidade e consumo, cultura.

\begin{abstract}
This paper is constituted by two complementary stages, the theoretical and the empirical ones, which are essential to reach the following aim we have proposed: confirming a change in the publicity praxis in which material and functional elements become less relevant and immaterial

${ }^{1}$ Professora efetiva do Departamento de Comunicação Social da UFS (Universidade Federal do Sergipe), curso Publicidade e Propaganda. Doutora em Comunicação Social pela Universidade Metodista de São Paulo - UMESP (2013); Doutorado-Sanduíche (PDSE) concluído e realizado em Carleton University, Ottawa, Canadá (2012); Mestre em Comunicação Midiática pela Universidade Estadual Paulista - UNESP (2009); Possui graduação em comunicação social pela Universidade Metodista de São Paulo (2000).Tem experiência na área de Comunicação, com ênfase em Comunicação Midiática, atuando principalmente nos seguintes temas: mídia, cultura, publicidade, consumo e pós-modernidade, representatividade de gênero. E-mail: renatamalta@ hotmail.com

${ }^{2}$ Doutorado em Comunicação Cientifica e Tecnológica pela Universidade Metodista de São Paulo (2000) e Pós Doutorado pela faculdade de Comunicação e Ciências da Informação da Universidade Complutense de Madrid. Atualmente é professor titular da Universidade Metodista de São Paulo e professor da Escola Superior de Propaganda e Marketing. Tem experiência na área de Comunicação, com ênfase em Comunicação com o mercado, atuando principalmente nos seguintes temas: comunicação integrada de marketing, novas tecnologias a serviço da comunicação com o mercado, marketing, publicidade e consumo. E-mail: galindo@ sti.com.br
\end{abstract}


Comunicação de mercado em um ambiente pós-moderno: A imaterialidade em cena.

de Renata Barreto Malta e Daniel dos Santos Galindo

and intangible elements more important. The theoretical discussion based on Cultural Studies and in authors who discourse about the Post Modernity and its consumption relations is the bottom-line of this research.

Keywords: publicity, post-modernity and consumption, culture.

\section{Resumen}

El artículo está constituido por dos etapas complementarias, la teórica y la empírica, esenciales para que el siguiente objetivo propuesto sea debidamente cumplido: confirmar un cambio de la praxis publicitaria en la cual elementos materiales y funcionales pasan a ser minimizados y elementos inmateriales e intangibles evidenciados. La discusión teórico-conceptual basada en los Estudios Culturales y en autores que discursan sobre la pos-modernidad y sus relaciones de consumo es el punto de partida de esta investigación.

Palabras-clave: publicidad, pos-modernidad y consumo, cultura.

\section{REFLEXÕES SOCIOCULTURAIS}

Assim como tantas outras pesquisas, este artigo parte da observação e da intuição de que um determinado fenômeno está em emergência. Trata-se de uma mudança no discurso publicitário, indissociável de uma transformação social. Esta indissociabilidade baseia-se na constatação de que qualquer produção cultural em uma dada sociedade reflete valores e preceitos ali presentes. Propomos um mergulho nos Estudos Culturais, principalmente nas obras de Raymond Williams, com a finalidade primeira de explicitar dita constatação. Esta pesquisa bibliográfica, ainda que exposta aqui de forma abreviada, é de extrema importância devido ao seu caráter teórico e empírico, passível de verificação, de observação. Entendemos a partir dela, como o autor ora citado estabeleceu uma relação arraigada entre o conteúdo presente nas obras literárias inglesas e a sociedade para qual tais obras foram escritas. Williams busca o entendimento da cultura por meio da literatura e da arte. $\mathrm{O}$ que nos parece relevante nesse processo, para esta pesquisa especificamente, é exatamente a relação que se estabelece entre as obras e a sociedade. Um caminho para se entender o sistema de vida, ou seja, as culturas e a sociedade a qual estas culturas se estabelecem, é a análise de suas obras. É seguindo este trajeto que Williams busca um retrato da sociedade inglesa, percorrendo os mais variados solos e 
Comunicação de mercado em um ambiente pós-moderno: A imaterialidade em cena. de Renata Barreto Malta e Daniel dos Santos Galindo

analisando um conjunto extenso de obras literárias, em um processo social-histórico. Um exemplo claro da dinâmica proposta pelo autor está em sua obra "O Campo e a Cidade: Na História e Na Literatura", 1990. Ali, o autor relata a importância cultural das ideias rurais, de como o passado rural (no século XX já se podia falar de passado rural) e a experiência rural estavam ligados a sentimentos retratados na literatura.

Mais além, atentamo-nos à real intenção do autor, não lhe interessava apenas expor o conteúdo que compunha seu objeto de estudo, sua verdadeira obsessão estava em refletir sobre as estruturas comuns suscetíveis à observação e análise nestas produções culturais. O estudo dessas estruturas revelaram a consciência e a prática de um grupo social, em um determinado período histórico. Williams buscou detalhar a aparição de certos elementos nas produções analisadas com a finalidade de identificar aspectos comuns que indicassem valores sociais em emergência, ou já estabelecidos, intrínsecos à cultura daquela sociedade. Percorrendo este caminho, vemos a necessidade de discorrer sobre a relação entre publicidade e cultura com o propósito de aclararmos que a publicidade é uma produção cultural e que, em tempos pós-modernos, sua relevância social se eleva. Para tanto, voltamos aos Estudos Culturais com o intuito de relacionar a publicidade a outros vocábulos em constante mutação de significado, vocábulos estes cuja definição não faz sentido procurar no dicionário. Observamos que à palavra cultura agregaram-se outros conceitos que a transportou de um terreno puramente concreto e material, para outra esfera, muito mais subjetiva e abstrata. De cultivo da terra ou de animais, chegou-se ao cultivo do espírito e da alma, elevando o ser culto a um universo restrito e elitizado. Chegamos, então, a outra definição, também subjetiva, mas muito mais democrática, em que a cultura passou a abarcar as práticas sociais e suas atividades cotidianas, sendo definida como todo um sistema de vida. Nesse trajeto, fica claro como o movimento aqui descrito, do concreto para o abstrato, do material para o imaterial, ocorreu com outros vocábulos de extrema importância para os Estudos Culturais. Literatura, de etimologia littera, remetia à alfabetização, ao ato de ler e escrever e, ao ganhar novos significados, elevou-se ao uso estético da linguagem escrita, à arte literária. A arte, que a princípio era definida como uma habilidade geral humana, passou a representar a concretização de um ideal de beleza, de perfeição, a expressão da subjetividade humana. Nesse percurso, algo revelador se sobressaiu, a percepção de que o vocábulo publicidade passou pela mesma metamorfose acima exposta, deixando o terreno do tangível e transpassando ao do 
Comunicação de mercado em um ambiente pós-moderno: A imaterialidade em cena. de Renata Barreto Malta e Daniel dos Santos Galindo

intangível. Se publicar ou propagar definia publicidade ou propaganda ${ }^{3}$, em seu sentido mais funcional, o interesse por uma produção artística, intimamente associada aos sentidos e à estética, concatenada ao contexto sociocultural, elevou a publicidade a uma forma de entretenimento ${ }^{4}$.

Assumimos, pois, que assim como outras obras sociais, como as artísticas e literárias, a produção publicitária é cultural e que a cultura não apenas se restringe a uma fonte a ser pesquisada pelo produtor com a finalidade de construir um discurso publicitário adequado, mas também, que ela é determinante e condutora desta produção. Entendemos, ainda, que o contexto social é bastante esclarecedor e, por esta razão, aceitamos o desafio de elucidar as características da atual sociedade, complexa e de nomenclaturas variadas, dependendo das lentes utilizadas para vislumbrá-la. Percebemos, em nossa pesquisa bibliográfica, que a pós-modernidade está marcada por transformações sem precedentes, originadas da fluidez de sua estrutura que perpassa à identidade de seus agentes. Quando Bauman condiciona a adesão social ao consumo, ele não se refere ao consumo como forma de satisfação das necessidades materiais. Vamos às compras "pelo tipo de imagem que gostaríamos de vestir e por modos de fazer com que os outros acreditem que somos o que vestimos; por maneiras de fazer novos amigos que queremos e de nos desfazer dos que não mais queremos..." (BAUMAN, 2001:87). A vida organizada em torno do consumo não é orientada por normas fixas e sólidas, mas pela sedução, por desejos. A não solidez é exatamente a característica que provavelmente melhor simbolize a pós-modernidade nos mais diversos âmbitos. A fluidez ou liquidez de suas estruturas modifica todas as relações sociais. Em um período de instituições tradicionais fragilizadas, exatamente devido ao derretimento dos sólidos, a comunicação midiática aparece como importante fonte de informação e de histórias que contribuem para a nossa formação identitária. É neste sentido que a produção publicitária se mostra ainda mais relevante em um ambiente pós-moderno.

Assim como visualizamos um solo movediço como "base" para estas instituições, também visualizamos identidades disformes e cambiantes para os agentes, ou membros desta sociedade, considerando que a identidade "costura" o sujeito à estrutura (Hall, 2000). Provavelmente, "grupo de indivíduos" seja a melhor definição para os consumidores que atuam

\footnotetext{
${ }^{3}$ Como ressalta Galindo (2002), seguindo as "Normas-Padrão da atividade publicitária", partimos da igualdade dos termos: "Publicidade ou Propaganda: é, nos termos do art. $2^{\circ}$ de Decreto n. 57.690/66, qualquer forma remunerada de difusão de ideias, mercadorias, produtos ou serviços por parte de um anunciante identificado" (Conselho Executivo de Normas-Padrão, 1998: 6).

${ }^{4}$ Entendemos por entretenimento uma performance que capta a atenção do espectador e distrai; uma diversão.
} 
nesse contexto social, e definir sua(s) identidade(s) é, claramente, complexo. Bauman (2007), metaforicamente, associa as identidades na pós-modernidade a crostas vulcânicas que vez ou outra endurecem sobre a lava, mas que, impossibilitadas de deterem o fluxo, derretem e se fundem novamente, antes de terem tempo para endurecerem e se fixarem. Assim, o sujeito pósmoderno não possui uma identidade fixa e estável, ao contrário, o que se pode observar são sujeitos de identidades inacabadas, fragmentadas e abertas. As identidades se tornaram “desvinculadas - desalojadas - de tempos, lugares, histórias e tradições específicos e parecem 'flutuar livremente," (HALL, 2000:75), assim como o ambiente onde elas habitam. A instabilidade e volatilidade de todas estas identidades garantem uma possibilidade que em períodos de identidade fixa e sólida não nos parecia disponível. A capacidade de selecionar e descartar identidades, o que, na pós-modernidade, caracteriza nossa liberdade individual, intrinsecamente relacionada ao papel de consumidor.

Observamos, também, que estamos diante de um período social que pode ser definido como pós-material. Possivelmente o excesso de bens materiais e a velocidade a qual estes bens invadiram o mercado tenham provocado no consumidor uma certa exaustão e, assim, gerado ansiedades por outras formas, não materiais. Jensen (1999) sugere que a sociedade na qual estamos adentrando (ou já adentramos) não deixará de lado os benefícios conquistados durante toda a trajetória do homem, porém, os valores predominantes dessa sociedade, a qual ele denomina "Sociedade dos Sonhos", o que para nós é mais uma nomenclatura para sociedade pósmoderna, são outros. Pós-modernos, passamos a ser seduzidos muito mais por valores simbólicos e intangíveis. As histórias e o valor emocional que eles agregam seriam mais sedutores nessa nova sociedade que o valor do produto em si. Ao descrever o que Lipovetsky (2004) nomeia de tempos hipermodernos, o autor afirma que o vazio do consumidor (pós)moderno preenchido pelos objetos adquiridos é, na verdade, preenchido por algo imaterial que acompanha tais objetos.

Na verdade, o que nutre a escala consumista é indubitavelmente tanto a angústia existencial quanto o prazer associado às mudanças, o desejo de intensificar e reintensificar o cotidiano. Talvez esteja aí o desejo fundamental do consumidor hipermoderno; renovar sua vivência do tempo, revivificá-la por meio das novidades que se oferecem como simulacros de aventura (LIPOVETSKY, 2004:79). 
De alguma forma, estaríamos buscando valores que representam um mundo ideal que não estaria baseado no consumismo, mas sim na realização de sonhos. O lugar utópico ${ }^{5}$ que tais valores representam não seria o cotidiano mundano que vivenciamos hoje, no qual os produtos materiais estão inseridos, mas sim, um mundo imaginário, onde os sonhos e as fantasias se fazem reais. Desse modo, as estratégias de marketing comunicacional das corporações estariam voltadas à divulgação desse mundo utópico e não mais do produto em si.

Ressaltamos que partindo da mera observação e da pesquisa bibliográfica, cujos passos foram brevemente expostos neste momento, vimos a necessidade de adentrar o campo da comprovação empírica. Inspirados pela metodologia aplicada por Raymond Williams em que, por meio da análise de produções culturais, pode-se chegar à compreensão de fenômenos socioculturais, nossa pesquisa se direcionou às análises de conteúdo, apresentando como hipótese que: considerando como premissa que estamos diante de uma nova lógica social em que o intangível presente nos discursos midiáticos causa mais fascínio do que a materialidade, há uma tendência de que o discurso publicitário minimize elementos funcionais e tangíveis e evidencie valores simbólicos e intangíveis, atrelando a marca e/ou produto a estes valores.

\section{METODOLOGIA APLICADA: ANÁLISE DE CONTEÚdO}

Por meio da análise de conteúdo quantitativa de peças publicitárias criteriosamente definidas e selecionadas, pretendemos entender a estrutura das mesmas no sentido de quão evidente é a presença de elementos materiais e imateriais, confirmando ou refutando a hipótese acima apresentada. De forma comparativa, dos anos 60 aos anos 2000, considerando cada década um grupo, realizamos uma análise de conteúdo quantitativa em vídeos publicitários televisivos com a finalidade de mensurar em frequência temporal quanto do áudio e da imagem é constituído por elementos tangíveis e intangíveis.

Como critério para a seleção das peças publicitárias para análise, optamos por vídeos veiculados pela televisão de um segmento específico, o automobilístico. Para compor o corpus, selecionamos vídeos publicitários produzidos em cinco décadas distintas (60, 70, 80, 90 e 2000) para as seguintes montadoras: Ford, Volkswagen, General Motors (Chevrolet) e Fiat, levando em

\footnotetext{
5 Aqui, utópico tem o sentido de qualquer descrição imaginativa de uma sociedade ideal, fundamentada em leis justas e no bem-estar da coletividade. Os indivíduos dessa sociedade utópica vivem em condições perfeitas.
} 
Comunicação de mercado em um ambiente pós-moderno: A imaterialidade em cena. de Renata Barreto Malta e Daniel dos Santos Galindo

conta a importância das mesmas para o desenvolvimento do setor. Devido à impossibilidade de acesso e análise de todos os vídeos publicitários produzidos no período acima mencionado, adotamos como base o arquivo digital da Revista Quatro Rodas (consultado em março de 2013), considerando que este possui um acervo de vídeos publicitários confiável e amplo e que se trata de uma revista consagrada que acompanha a história do automóvel no país. A partir desse universo, desconsideramos os vídeos estrangeiros, os que possuíam mais de 30 segundos (exceto os da década de 60) e os que apresentavam problemas técnicos, em áudio ou imagem. Explicitamos que a maior parte dos vídeos produzidos na década de 60 tem a duração de um minuto. Assim, para esse período, selecionamos vídeos de 30 segundos e 1 minuto. A partir da década de 70, a tendência passou a ser a produção de peças publicitárias de 30 segundos, o que permaneceu nas décadas seguintes. Adotamos um critério de seleção randômica por meio de sorteio para a coleta da amostragem de trinta e cinco vídeos de cada década (anos 80, 90 e 2000), exceto aquelas em que o universo total de vídeos arquivados não atingia esta quantia (anos 60, com 26 vídeos, e anos 70, com 29), totalizando um corpus de 160 peças publicitárias. Nosso propósito, ao adotar esse procedimento metodológico, foi tornar a seleção do corpus não tendenciosa e representativa. Estipulou-se, cientifica e estatisticamente, que para que uma amostra seja probabilística e generalizável é preciso que todos os membros da população do grupo a ser estudado tenham as mesmas chances de serem selecionados e que esta amostra seja formada por pelo menos 35 integrantes desse grupo, independentemente do tamanho da população inicial (universo) (AAKER, 2004).

O objetivo primordial dessa análise é verificar quantitativamente e comparativamente em que medida elementos considerados intangíveis se tornam mais evidentes em detrimento de elementos tangíveis nas mensagens publicitárias, década por década. É importante ressaltar o critério adotado para determinar o que é tangível e intangível. No que diz respeito ao áudio, foi considerado tangível sempre que se falava de elementos materiais do produto, em locução, diálogo ou jingle. Citamos como exemplo a velocidade, desempenho do motor, design, entre outros. Tudo o que era dito em locução ou diálogo e não se referia aos elementos funcionais do carro ou marca, assim como trilha sonora, foi considerado intangível. Quanto à imagem, classificamos como tangível qualquer imagem em que o carro e seus elementos funcionais eram focados, assim como letterings que continham informações sobre estes elementos ou logo representativo da marca; e intangível tudo o que não se referia ao carro. Nos casos em que a 
Comunicação de mercado em um ambiente pós-moderno: A imaterialidade em cena.

de Renata Barreto Malta e Daniel dos Santos Galindo

representação gráfica da marca aparecia em tamanho pequeno e no canto da tela e o foco estava em elementos intangíveis, codificamos como intangível.

Ao calculamos as médias em segundos de cada variável, separadamente de década por década, obtivemos o resultado representado no seguinte quadro (tangaudio = áudio tangível; tangimag = imagem tangível; intangaudio = áudio intangível; intangimag = imagem intangível):

Quadro 1: Médias de frequência temporal das variáveis analisadas dos anos 60 aos 2000

\begin{tabular}{|ccccc|}
\hline Anos & tangaudio & tangimag & intangaudio & Intangimag \\
60 & 20.35 & 23.5 & 9.65 & 6.5 \\
70 & 25.62 & 23.45 & 4.38 & 6.55 \\
80 & 19.37 & 23.89 & 10.63 & 6.11 \\
90 & 17.23 & 20.77 & 12.77 & 9.23 \\
2000 & 7.37 & 11.09 & 22.63 & 18.91 \\
\hline
\end{tabular}

Para um melhor entendimento dos dados, transformamos as informações acima em um gráfico de colunas 3D. Assim como no quadro, os números representam as médias em segundos de cada variável, considerando um total de 30 segundos (cada peça publicitária).

Gráfico 1: Representação comparativa das médias de frequência temporal nas variáveis analisadas dos anos 60 aos 2000

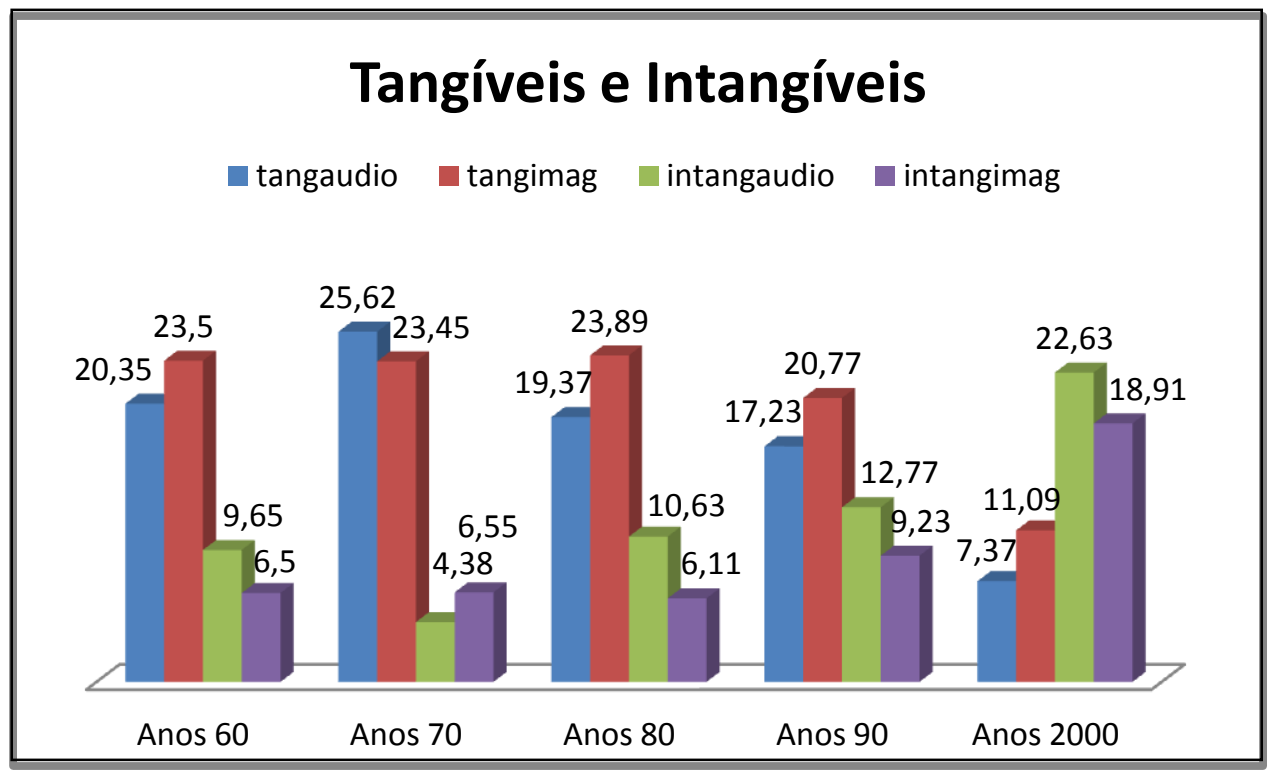


Apenas ao observar a frequência temporal das variáveis, de década a década, percebemos nitidamente uma inversão de resultados no que diz respeito a tangíveis e intangíveis quando chegamos aos anos 2000. Assim, se até os anos 90 havia uma prevalência de elementos tangíveis, tanto em áudio como em imagem, nos anos 2000 os intangíveis passaram a predominar. A partir desses dados, procuramos comparar as médias dos tempos de cada década, considerando cada variável, por meio de uma análise estatística utilizando o programa proc mixed dos programa SAS. Comparamos os números obtidos entre as décadas de 60 e 70; 70 e 80; 80 e 90; 90 e 2000. Aplicamos como ponto de corte "P menor que 0,05", objetivando observar se as diferenças entre as médias obtidas em cada década eram estatisticamente significativas. Os quadros abaixo são o resultado das comparações múltiplas entre as médias, de cada variável.

Quadro 2: Comparação múltipla entre as médias obtidas da variável “áudio tangível” dos anos 60 aos 2000

Model Information

Data Set WORK.A

Dependent Variable Tangaudio

Covariance Structure Unstructured

Subject Effect Peca

Estimation Method REML

Residual Variance Method None

Fixed Effects SE Method Model-Based

Degrees of Freedom Method Between-Within 
Comunicação de mercado em um ambiente pós-moderno: A imaterialidade em cena. de Renata Barreto Malta e Daniel dos Santos Galindo

Differences of Least Squares Means

\begin{tabular}{llllllllll}
\multicolumn{7}{c}{ Standard } \\
Effect & anos & _anos & Estimate & Error & DF & $\mathrm{t}$ Value & $\operatorname{Pr}>|\mathrm{t}|$ & Adjustment & Adj P \\
anos & 60 & 70 & -5.2745 & 2.4389 & 155 & -2.16 & 0.0321 & Tukey-Kramer & $\mathbf{0 . 1 9 9 5}$ \\
anos & 70 & 80 & 6.2493 & 2.2675 & 155 & 2.76 & 0.0066 & Tukey-Kramer & $\mathbf{0 . 0 5 0 6}$ \\
anos & 80 & 90 & 2.1429 & 2.1586 & 155 & 0.99 & 0.3224 & Tukey-Kramer & $\mathbf{0 . 8 5 8 3}$ \\
anos & 90 & 2000 & 9.8571 & 2.1586 & 155 & 4.57 & $<.0001$ & Tukey-Kramer & $<.0001$
\end{tabular}

Quadro 3: Comparação múltipla entre as médias obtidas da variável "áudio intangível” dos anos 60 aos 2000

\begin{tabular}{|rl|}
\hline Model Information \\
Data Set & WORK.A \\
Dependent Variable & Intangaudio \\
Covariance Structure & Unstructured \\
Subject Effect & Peca \\
Estimation Method & REML \\
Residual Variance Method & None \\
Fixed Effects SE Method & Model-Based \\
Degrees of Freedom Method & Between-Within
\end{tabular}


Comunicação de mercado em um ambiente pós-moderno: A imaterialidade em cena. de Renata Barreto Malta e Daniel dos Santos Galindo

Differences of Least Squares Means

\begin{tabular}{llllllllll}
\multicolumn{7}{c}{ Standard } \\
Effect & anos & _anos & Estimate & Error & DF & t Value & Pr $>|t|$ & Adjustment & Adj P \\
anos & 60 & 70 & 5.2745 & 2.4389 & 155 & 2.16 & 0.0321 & Tukey-Kramer & $\mathbf{0 . 1 9 9 5}$ \\
anos & 70 & 80 & -6.2493 & 2.2675 & 155 & -2.76 & 0.0066 & Tukey-Kramer & $\mathbf{0 . 0 5 0 6}$ \\
anos & 80 & 90 & -2.1429 & 2.1586 & 155 & -0.99 & 0.3224 & Tukey-Kramer & $\mathbf{0 . 8 5 8 3}$ \\
anos & 90 & 2000 & -9.8571 & 2.1586 & 155 & -4.57 & $<.0001$ & Tukey-Kramer & $<.0001$
\end{tabular}

Quadro 4: Comparação múltipla entre as médias obtidas da variável “imagem tangível” dos anos 60 aos 2000

\begin{tabular}{|rl|}
\hline Model Information \\
Data Set & WORK.A \\
Dependent Variable & Tangimag \\
Covariance Structure & Unstructured \\
Subject Effect & Peca \\
Estimation Method & REML \\
Residual Variance Method & None \\
Fixed Effects SE Method & Model-Based \\
Degrees of Freedom Method & Between-Within
\end{tabular}

Differences of Least Squares Means

\begin{tabular}{llllllllll}
\multicolumn{7}{c}{ Standard } \\
Effect & anos & _anos & Estimate & Error & DF & t Value & Pr $>|t|$ & Adjustment & Adj P \\
anos & 60 & 70 & 0.05172 & 2.2108 & 155 & 0.02 & 0.9814 & Tukey-Kramer & $\mathbf{1 . 0 0 0 0}$ \\
anos & 70 & 80 & -0.4374 & 2.0555 & 155 & -0.21 & 0.8318 & Tukey-Kramer & $\mathbf{0 . 9 9 9 5}$ \\
anos & 80 & 90 & 3.1143 & 1.9568 & 155 & 1.59 & 0.1135 & Tukey-Kramer & $\mathbf{0 . 5 0 5 1}$ \\
anos & 90 & 2000 & 9.6857 & 1.9568 & 155 & 4.95 & $<.0001$ & Tukey-Kramer & $<.0001$
\end{tabular}


Comunicação de mercado em um ambiente pós-moderno: A imaterialidade em cena.

Quadro 5: Comparação múltipla entre as médias obtidas da variável "imagem intangível” dos anos 60 aos 2000

Model Information

Data Set WORK.A

Dependent Variable Intangimag

Covariance Structure Unstructured

Subject Effect Peca

Estimation Method REML

Residual Variance Method None

Fixed Effects SE Method Model-Based

Degrees of Freedom Method Between-Within

Differences of Least Squares Means

Standard

Effect anos_anos Estimate Error DF $t$ Value $\operatorname{Pr}>|t|$ Adjustment Adj P

$\begin{array}{lllllllll}\operatorname{anos} & 60 & 70 & -0.05172 & 2.2108 & 155 & -0.02 & 0.9814 & \text { Tukey-Kramer } \mathbf{1 . 0 0 0 0}\end{array}$

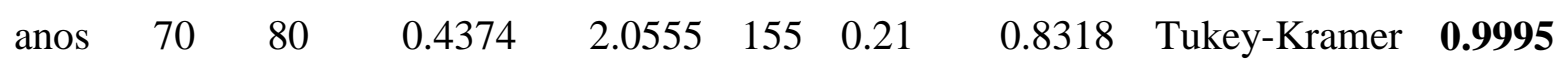

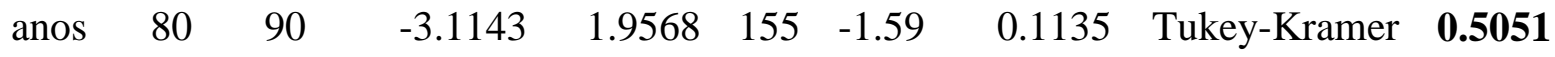

$\begin{array}{lllllllll}\text { anos } & 90 & 2000 & -9.6857 & 1.9568 & 155 & -4.95 & <.0001 & \text { Tukey-Kramer } \quad<.0001\end{array}$

Ao observar os resultados acima expostos, percebemos que, estatisticamente, a única diferença significativa está entre as décadas de 90 e 2000 no que diz respeito a áudio e imagem. Portanto, entendemos que a prevalência de elementos intangíveis em detrimento dos tangíveis em peças publicitárias do setor automobilístico não se deu de forma processual ou crescente, dos anos 60 aos anos 2000, mas sim abruptamente, como em uma ruptura de tendências a partir do início dos anos 2000. Baseando-nos nestes resultados, confirmamos a hipótese de que elementos intangíveis ou imateriais passaram a predominar no discurso publicitário de forma evidente e que 
Comunicação de mercado em um ambiente pós-moderno: A imaterialidade em cena. de Renata Barreto Malta e Daniel dos Santos Galindo

elementos tangíveis ou funcionais perderam espaço de tempo, considerando o corpus desta pesquisa: peças publicitárias televisivas do setor automobilístico.

\section{INTERPRETAÇÃO DOS RESULTADOS}

Foquemo-nos, então, à interpretação dos resultados obtidos a partir dessa primeira análise. O gráfico 1, em colunas, apresentado no tópico anterior e representando os dados do quadro que o antecede, demonstra claramente que entre as décadas de 60 e 90 o tangível predominou. Nessas décadas, em vídeos de 30 segundos, o espaço de tempo destinado a elementos materiais ou funcionais do produto ou da marca varia, em média, entre pouco mais de 17 segundos a pouco mais de 25 segundos, no que diz respeito ao áudio, e entre quase 21 segundos a quase 24 segundos, no que se refere à imagem. Se até o fim dos anos 90 havia uma prevalência de tangíveis, ou seja, da evidência de características funcionais e materiais no discurso publicitário, quando chegamos aos anos 2000, as colunas do gráfico praticamente são invertidas. Os elementos tangíveis mensurados em peças publicitárias dessa década passam a representar, em média, pouco mais de 7 segundos, quando o foco é o áudio, e pouco mais de 11 segundos ao tratarmos das imagens. Está clara a confirmação de que os anos 2000 marcam uma transformação de tendências. Ainda havia, no entanto, uma dúvida. Será que esta mudança aparentemente explícita poderia ser comprovada estatisticamente? Para responder a esse questionamento realizamos uma análise estatística comparando os resultados das médias entre as décadas de 60 e 70; 70 e 80; 80 e 90; 90 e 2000. Deparamo-nos com um resultado bastante revelador. Apenas as diferenças entre as médias das décadas de 90 e 2000 eram estatisticamente significativas $(\mathrm{P}<0,05)$, em ambas as variáveis, áudio e imagem.

Isso nos mostra que estamos diante de um fenômeno que não ocorreu de forma processual ou crescente, mas sim de maneira brusca, em uma ruptura, que alterou profundamente as características do discurso publicitário. Retomemos, então, a indissociabilidade entre produção cultural e sociedade, sobre a qual já discorremos. Por meio das análises de suas obras chegamos a resultados que denotam comportamentos, práticas e valores em vigor na sociedade. Assim, ao analisar peças publicitárias produzidas em cinco décadas distintas, percebemos que foi apenas na última delas, nos anos 2000, que a publicidade realmente alterou seu modo de comunicar. Se o imaterial ou o intangível passou a preponderar, isto significa que existe uma visível consonância 
Comunicação de mercado em um ambiente pós-moderno: A imaterialidade em cena. de Renata Barreto Malta e Daniel dos Santos Galindo

entre a publicidade e a sociedade pós-moderna, considerando que, segundo a revisão bibliográfica realizada para esta pesquisa, vivenciamos um período pós-material e fluido. Como vimos, Jensen (1999) afirma que neste novo momento social, ao qual adentramos, nossas atenções se voltam às histórias e sentimentos e o racional deixa de surtir tanto efeito persuasivo junto ao público. Seguindo essa lógica, nada indicaria mais simetria entre a sociedade e suas produções culturais do que os resultados aqui encontrados. Se é apenas na Sociedade dos Sonhos (Jensen, 1999) que passamos a vivenciar um período pós-material, sem precedentes, é a partir dela que o discurso voltado ao tangível deixou de fazer total sentido. A constatação dessa premissa por meio da pesquisa empírica reforça com propriedade o que havíamos dissertado, baseando-nos em autores que se dedicaram a desbravar a pós-modernidade.

Já que o consumismo de hoje não é motivado pela busca da satisfação de necessidades e sua comunhão com o prazer se faz presente, como afirma Lipovetsky (2004), os anseios dos consumidores estão voltados a formas imateriais. Suas aspirações estão centradas na realização de sonhos e em valores representativos de um mundo imaginário no qual os objetos estão inseridos. Falar da funcionalidade desses objetos é ilógico frente a este cenário. Movido pela gana por experiências e sensações, o consumidor pós-moderno não se encanta mais por bens materiais como o fazia em outros períodos sociais. A análise comparativa de década a década foi de grande valia para a constatação de tais reflexões teóricas. Os anos 2000 são, assim, um marco de passagem de um modelo social a outro, ainda que seja difícil pontuar com exatidão onde começa e onde termina um tipo de sociedade. Podemos afirmar, com bases teóricas e empíricas, que houve uma ruptura e que um novo período social emergiu. Para comunicar sua mensagem em tempos pós-modernos, a comunicação de mercado busca no intangível sua principal forma de persuadir consumidores ávidos pelo simbólico.

Existem, ainda, algumas observações que merecem ser mencionadas. Ao destinarmos nosso foco de análise nos anos 2000, notamos que, embora o fenômeno acima descrito tenha se confirmado nas duas variáveis, áudio e imagem, houve uma diferença do tempo destinado a elementos intangíveis entre ambas. Não podemos nos esquecer de que quando se fala em produção audiovisual é preciso entender que áudio e imagem não são elementos dissociados ou complementares. Contrariando a ideia de acréscimo, entendemos o audiovisual como um contrato, já que uma percepção influencia a outra e a transforma: não 'vemos' a mesma coisa quando ouvimos; não 'ouvimos’ a mesma coisa quando vemos. Para Michel Chion (2011), o 
Comunicação de mercado em um ambiente pós-moderno: A imaterialidade em cena. de Renata Barreto Malta e Daniel dos Santos Galindo

contrato audiovisual é marcado pelo princípio da síncrese, que permite estabelecer uma relação imediata e necessária entre qualquer coisa que se vê e qualquer coisa que se ouve. Os sons, tal como as imagens, montam-se: são fixados em porções que podem ser cortadas, deslocadas à vontade. Assim, a banda sonora de uma produção é constituída por várias camadas realizadas e dispostas de forma independente. Esse entendimento é de grande importância no que diz respeito à produção, já que a síncrese não é algo natural, ela deve ser construída. A unidade entre som e imagem é uma ilusão, ela existiria se os sons fossem captados no momento de gravação das cenas e não fossem alterados e editados no processo de montagem. A realidade é uma coisa e a sua transposição para a dimensão audiovisual é outra, mesmo que essa transposição busque um ar de realismo, visando um melhor simulacro.

Desse modo, estamos tratando de uma construção composta por sons e imagens que busca necessariamente uma síncrese. Percebemos que nesse processo, outros sons que não se relacionavam às propriedades materiais do produto foram privilegiados, mesmo, por vezes, quando a imagem remetia ao material. Se, em média, mostrou-se pouco mais de 11 segundos a materialidade do produto ou da marca, falou-se, em média, pouco mais de 7 , tendo como base um tempo total de 30 segundos. Portanto, temos pouco mais de $36 \%$ da imagem dos vídeos produzidos nos anos 2000 e, pouco mais de $23 \%$ do áudio destes vídeos destinados a aspectos tangíveis do produto ou da marca. Isso quer dizer, em uma simples interpretação de resultados, que quando se faz menção ao produto ou à marca, prefere-se mostrá-los a falar dos mesmos. Uma possível explicação para esse fato é que ao contar uma história a publicidade envolve o receptor com narrativas que não dizem respeito ao produto, mesmo que este esteja ali presente. Elas fazem uso de músicas, trilhas sonoras e outros recursos de áudio que não remetem à materialidade do mesmo, ainda que sua imagem apareça. Um dado que pode ser observado no processo de análise de conteúdo é que das 35 peças publicitárias produzidas nos anos 2000, parte do corpus desta pesquisa, 25 utilizaram música ou trilha sonora como recurso de áudio em destaque. Em destaque porque apenas consideramos trilha sonora ou música quando estas não foram empregadas como background. A utilização deste recurso demonstra uma preocupação em despertar sensações, já que a música é uma linguagem de múltiplos sentidos que ativa corpo e mente e trabalha com códigos culturais. "Longe de ser mera experiência estética, a experiência com música é também fisiológica, psicológica, mental, com o poder de nos fazer sentir" (SEKEFF, 2002:13). 
Comunicação de mercado em um ambiente pós-moderno: A imaterialidade em cena. de Renata Barreto Malta e Daniel dos Santos Galindo

Direcionamos, ainda, um olhar mais minucioso às peças publicitárias das décadas de $60 \mathrm{a}$ 90 que, diferentemente da maioria, privilegiaram elementos intangíveis em detrimento dos tangíveis em áudio e imagem. Não temos a intenção de responder a indagações sobre o porquê destas produções, já que para isso precisaríamos de uma pesquisa mais detalhada, provavelmente questionando produtores destes vídeos que destoaram do todo. Observamos um total de catorze peças, sendo quatro dos anos 60, quatro dos anos 80 e seis dos anos 90. Nitidamente suas narrativas contavam uma história ou apresentavam situações em que o produto não era o foco, mas que se associariam a ele ou à marca com o desenrolar do narrado. Portanto, as características da maior parte delas se diferenciam daquelas produzidas nos anos 2000. Das quatro criadas nos anos 60, apenas uma contava uma história em que o produto não seria protagonista. Trata-se da representação de uma trama de "mocinho e bandido", típica do cinema da época. A mulher em perigo é salva pelo herói e o carro apenas faz parte da narrativa como coadjuvante por ser o meio de transporte utilizado por ele. Podemos afirmar que esta era sim uma proposta singular para a época e que muito se assemelha ao que vemos hoje na publicidade brasileira, especificamente do setor automobilístico. Os demais vídeos em discrepância com o todo, nesta mesma década, apresentaram objetos ou situações que não estavam diretamente relacionados à materialidade do produto em questão, mas em seu desfecho, o receptor era direcionado a ele. Em uma delas, o foco eram regadores, comuns em postos de gasolina, remetendo à característica do carro anunciado: refrigerado a ar e que não precisava de água. Em outra, o som e a imagem na tela eram de molas, relacionadas à suspensão do carro em questão. A última, ainda dos anos 60, mostrava a imagem de uma banda dentro do veículo em foco, com som ambiente, para evidenciar o espaço do carro.

Nos anos 70 nenhuma das peças selecionadas dedicou maior tempo ao intangível do que ao tangível. Nos 80, assim como nos 60, somente um vídeo conta uma história assinada pela marca. Concatenada ao contexto sociocultural, essa peça mostra um homem prestes a ser fuzilado pelos militares da ditadura. Nos demais casos em que a imaterialidade dos elementos prepondera em produções dos anos 80, também se observa a apresentação de situações ou objetos que direcionam o consumidor ao tangível. Na primeira, são expostas cenas de invenções humanas que marcaram época, enfatizando a genialidade do ser humano. O carro da marca é apresentado como uma dessas invenções. Na segunda, corações e luzes tomam a cena, embalados a uma música que se converte em jingle e que, no final, formam o desenho do carro, 
Comunicação de mercado em um ambiente pós-moderno: A imaterialidade em cena. de Renata Barreto Malta e Daniel dos Santos Galindo

reconhecido por seu design característico. A última mostra um gol memorável de Pelé. Sua descrição também é direcionada à descrição do produto anunciado. Já nos anos 90, além da presença de um maior número de peças com elementos intangíveis em destaque, a maior parte delas (quatro) conta uma história. Em algumas, a relação com o produto já podia ser observada antes do final, em outras, o produto ou a marca apenas assinavam a narrativa. A primeira delas narra um diálogo entre um policial e Lazaroni, técnico da seleção brasileira de futebol na época, imbricada ao contexto histórico, a Copa do Mundo de 90. Outra adverte o consumidor a não fazer em casa, ou na rua, algumas situações perigosas. As primeiras dizem respeito ao carro, mas não à sua funcionalidade, já que as acrobacias que aparecem na tela não são possíveis de ser realizadas. A última cena desse vídeo mostra uma situação cotidiana de casal que deve ser evitada para não causar brigas. As duas últimas peças que contam histórias fazem parte de uma mesma campanha da marca. Em ambas, são representadas cenas de alemães tentando se passar por brasileiros, como é o caso de uma alemã vestida de baiana vendendo acarajé. Evidenciamos, ainda, duas peças dos anos 90 que privilegiaram o intangível em seu discurso, mas sempre com a proposta de apresentar algo que remetesse ao carro, como se viu em décadas anteriores. Em um dos casos, o motor se transforma em homens robotizados que correm. Em outra, aparece um estádio de futebol lotado com a torcida gritando "Parou por quê?". A pergunta era para o carro, apresentado em seguida.

Obviamente que ao chegarmos aos anos 2000 encontramos mais peças em que o intangível prevalece do que o contrário, já que é nesse período que ocorre a inversão de valores. Desse modo, não faremos aqui um detalhamento de todas elas. Pretendemos, apenas, destacar alguns exemplos que possam ser pertinentes no sentido de explicitar pontos comuns e tendências na produção publicitária do setor automobilístico dessa última década. A encenação de uma história é, sem dúvida, o modelo mais comum nas produções deste período, presente em mais da metade das peças ${ }^{6}$. Seguindo esta ideia, duas formas distintas de construção da narrativa são visíveis. Na primeira, a trama se desenvolve sem que o produto ou a marca façam parte dela. Podemos exemplificar com um dos vídeos que mostra as diferentes fases de vida de um homem, do nascimento à maturidade. A história é toda contada por meio de imagens em sincronia com uma trilha sonora. Nesse caso, o carro não faz parte da história, nem mesmo é sugerido o produto

\footnotetext{
${ }^{6} \mathrm{Na}$ argumentação da segunda análise trataremos mais especificamente desta questão, já que "encenação" foi uma das temáticas categorizadas para esta segunda análise quantitativa de conteúdo.
} 
Comunicação de mercado em um ambiente pós-moderno: A imaterialidade em cena.

de Renata Barreto Malta e Daniel dos Santos Galindo

ou a marca anunciados. Apenas no final o produto aparece, relacionado a valores simbólicos presentes na narrativa. No segundo formato, o produto, no caso o carro, está presente desde o início, mas sua relação com a história encenada é sutil, já que ele não se sobressai. Os holofotes estão voltados a outros elementos, normalmente intangíveis, que compõe a narrativa. Um exemplo é uma peça analisada em que um rapaz atola o carro em uma floresta. Ao tentar descer do carro, ele se depara com animais selvagens. Assustado, fecha a porta. Aqui, a ficção irrompe e, antropomorfizados, os animais começam a cantar e dançar para ele. Somente nos últimos segundos o carro passa a ser protagonista. Queremos aclarar que ao exemplificar buscamos apresentar de forma mais compreensível as características comuns presentes no discurso publicitário das produções analisadas. No entanto, sabemos que a descrição está aquém da demonstração, principalmente no caso de produção audiovisual.

\section{CONCLUSÃO}

O trajeto percorrido para o desenvolvimento desta pesquisa teve a observação e a intuição como princípios. Vislumbramos um fenômeno sociocultural emergente refletido na comunicação de mercado que demandava investigação teórica e empírica. Rumamos, primeiramente, a estradas nas quais a teoria reinava. Fomos diretamente às fontes originais de autores que desbravaram a cultura e a transmutaram para o cerne do processo que tem como meta a compreensão social. Nossa primeira conclusão foi a indissociabilidade entre qualquer produção cultural e os valores e preceitos que regem a sociedade para a qual tais obras são comunicadas. Compreendemos, a partir dessa constatação teórica, que produções culturais são fontes extremamente ricas a serem analisadas na busca de um entendimento social. Devemos mencionar que nessa etapa de nossa jornada fomos inspirados pela metodologia aplicada por um autor em especial, Raymond Williams, um dos fundadores dos Estudos Culturais.

Seguimos rumo a terrenos extremamente férteis, conduzidos por autores que abriram passagem para a pós-modernidade. Chegamos, assim, a nossa próxima conclusão, a de que esse período social está marcado por transformações sem precedentes, definido como pós-material. Pós-modernos, passamos a ser seduzidos muito mais por valores simbólicos e intangíveis do que pela materialidade dos objetos que conosco vivem. 
Comunicação de mercado em um ambiente pós-moderno: A imaterialidade em cena. de Renata Barreto Malta e Daniel dos Santos Galindo

Seguimos, então, um percurso regido pelo empírico. Certamente sob a orientação teórica a seguinte hipótese emergiu: considerando como premissa que estamos diante de uma nova lógica social em que o intangível presente nos discursos midiáticos causa mais fascínio do que a materialidade, há uma tendência de que o discurso publicitário minimize elementos funcionais e tangíveis e evidencie valores simbólicos e intangíveis, atrelando a marca e/ou produto a estes valores. Com o intuito de confirmá-la ou refutá-la, optamos por um método fincado na objetividade, a análise quantitativa de conteúdo comparativa de produções publicitárias de diferentes momentos sociais. Nosso objetivo não estava centrado apenas em observar se essa mudança do discurso publicitário se confirmaria, mas também, em constatar se ela ocorreu de forma processual ou abrupta.

Decidimos pela seleção de um corpus constituído por peças publicitárias do setor automobilístico veiculadas pela televisão, produzidas em cinco décadas distintas, dos anos 60 aos 2000. Partimos para a análise de conteúdo que tinha como meta a mensuração da quantidade de tempo despendida a elementos tangíveis e intangíveis, a partir do corpus. A interpretação dos resultados obtidos nos levou à confirmação de nossa hipótese. Concluímos, assim, que a publicidade brasileira, considerando o corpus desta pesquisa, alterou seu modo de comunicar, minimizando elementos tangíveis relacionados à materialidade de produtos e marcas, e enfatizando aspectos intangíveis, associados ao simbólico. Obtivemos, ainda, uma importante constatação por meio da pesquisa empírica, que esse fenômeno acima descrito não ocorreu de forma processual, mas abruptamente, em um período bastante específico. Se até a década de 90 a materialidade prevalecia, nos anos 2000, o imaterial ganhou a cena. Vimos que esse último período é, assim, um marco de passagem de um modelo social a outro, mesmo diante da dificuldade em determinar onde começa e onde termina um tipo de sociedade. Comprovamos que para comunicar sua mensagem em um período pós-material, a publicidade, especificamente do setor automobilístico, busca no intangível sua principal forma de persuadir consumidores.

\section{REFERÊNCIAS BIBLIOGRÁFICAS}

AAKER, D. A Pesquisa de Marketing. São Paulo: Atlas, 2004.

BARDIN, L. Análise de Conteúdo. Lisboa: Edições 70, 2009. 
Comunicação de mercado em um ambiente pós-moderno: A imaterialidade em cena.

de Renata Barreto Malta e Daniel dos Santos Galindo

BARBOSA, I. S. (Org.), Os Sentidos da Publicidade: Estudos Interdisciplinares. São Paulo: Thomson, 2005.

BAUDRILlARD, J. Da Sedução. Campinas: Papirus, 1991. . A Sociedade de Consumo. Lisboa: Edições 70, 1995.

BAUMAN, Z. Modernidade Líquida. Rio de Janeiro: Zahar, 2001. . Vida Líquida. Rio de Janeiro: Zahar, 2007. . Tempos Líquidos. Rio de Janeiro: Zahar, 2007. . Vida para Consumo. Rio de Janeiro: Zahar, 2008.

CANCLINI, G. N. Culturas Híbridas: Estratégias para Entrar e Sair da Modernidade. São Paulo: Edusp, 2008.

CHION, M. A Audiovisão, Som e Imagem no Cinema. Lisboa: Edições Texto \& Grafia. 2011.

GALINDO, D. Propaganda Inteira \& Ativa. São Paulo: Futura, 2002.

HALL, S. A Identidade Cultural na Pós-Modernidade. Rio de Janeiro: DP\&A, 2000.

JENSEN, R. The Dream Society: How The Coming Shift From Information to Imagination Will Transform Your Business. New York: McGraw-Hill, 1999.

LIPOVETSKY, G. A era do vazio: Ensaios sobre o Individualismo Contemporâneo. Lisboa: Antropos, 1989.

SALMON. C. Storytelling: La Máquina de Fabricar Historias y Formatear las Mentes. Barcelona: Península, 2008.

SEKEFF, M. L. Da Música: Seus Usos e Recursos. São Paulo: Editora UNESP, 2002. . Os Tempos Hipermodernos. São Paulo: Barcarola, 2004.

VESTERGAARD, T. ; SCHRODER, K. A Linguagem da Propaganda. São Paulo: Martin Fontes, 1994.

WILliAMS. R. Cultura e sociedade. São Paulo: Cia. Nacional, 1969. . Marxismo e Literatura. Rio de Janeiro: Zahar Editores, 1979. . Problems in Materialism and Culture: Selected Essays. London: Verso Editions and NLB, 1980. . O Campo e a Cidade: Na História e Na Literatura. São Paulo: Companhia das Letras, 1990. 
Comunicação de mercado em um ambiente pós-moderno: A imaterialidade em cena. de Renata Barreto Malta e Daniel dos Santos Galindo

Artigo submetido: 14/05/2014

Artigo aprovado: 09/11/2014 